\title{
Correction to: The efficacy of etanercept as anti-breast cancer treatment is attenuated by residing macrophages
}

Elnaz Shirmohammadi ${ }^{1}$, Seyed-Esmaeil Sadat Ebrahimi ${ }^{1}$, Amir Farshchi ${ }^{2}$ and Mona Salimi ${ }^{3 *}$

\section{Correction to: BMC Cancer 20, 836 (2020) \\ https://doi.org/10.1186/s12885-020-07228-y}

Following publication of the original article [1], the authors report the following errors in their article:

1 In the Background section, the last sentence of the first paragraph has been corrected to the following: The secreted factors reprogram the surrounding stroma with the aim of neutralizing the impact of various inducers disrupting the survival of the cancer cells. It was originally published as: The secreted factors reprogram the surrounding stroma with the aim of neutralizing the impact of various intruders disrupting the survival of the cancer cells.

2. Figure 1 legend is incorrect. ${ }^{* * *} P<0.001$ (not 0.0001 )

3. Figure 2 legend is incorrect. ${ }^{* * * *} P<0.001$ (not 0.0001 )

4. Updated Fig. 3 and Fig. 4 are published in this correction article.

5. Figure 5 legend is incorrect. ${ }^{* * * *} P<0.001$ (not 0.0001 )

The original article can be found online at https://doi.org/10.1186/s12885020-07228-y.

*Correspondence: salimimona@pasteur.ac.ir

${ }^{3}$ Physiology and Pharmacology Department, Pasteur Institute of Iran, P.O. Box: 13164, Tehran, Iran

Full list of author information is available at the end of the article

C C The Author(s). 2020 Open Access This article is licensed under a Creative Commons Attribution 4.0 International License, which permits use, sharing, adaptation, distribution and reproduction in any medium or format, as long as you give appropriate credit to the original author(s) and the source, provide a link to the Creative Commons licence, and indicate if changes were made. The images or other third party material in this article are included in the article's Creative Commons licence, unless indicated otherwise in a credit line to the material. If material is not included in the article's Creative Commons licence and your intended use is not permitted by statutory regulation or exceeds the permitted use, you will need to obtain permission directly from the copyright holder. To view a copy of this licence, visit http://creativecommons.org/licenses/by/4.0/ The Creative Commons Public Domain Dedication waiver (http://creativecommons.org/publicdomain/zero/1.0/) applies to the data made available in this article, unless otherwise stated in a credit line to the data. 


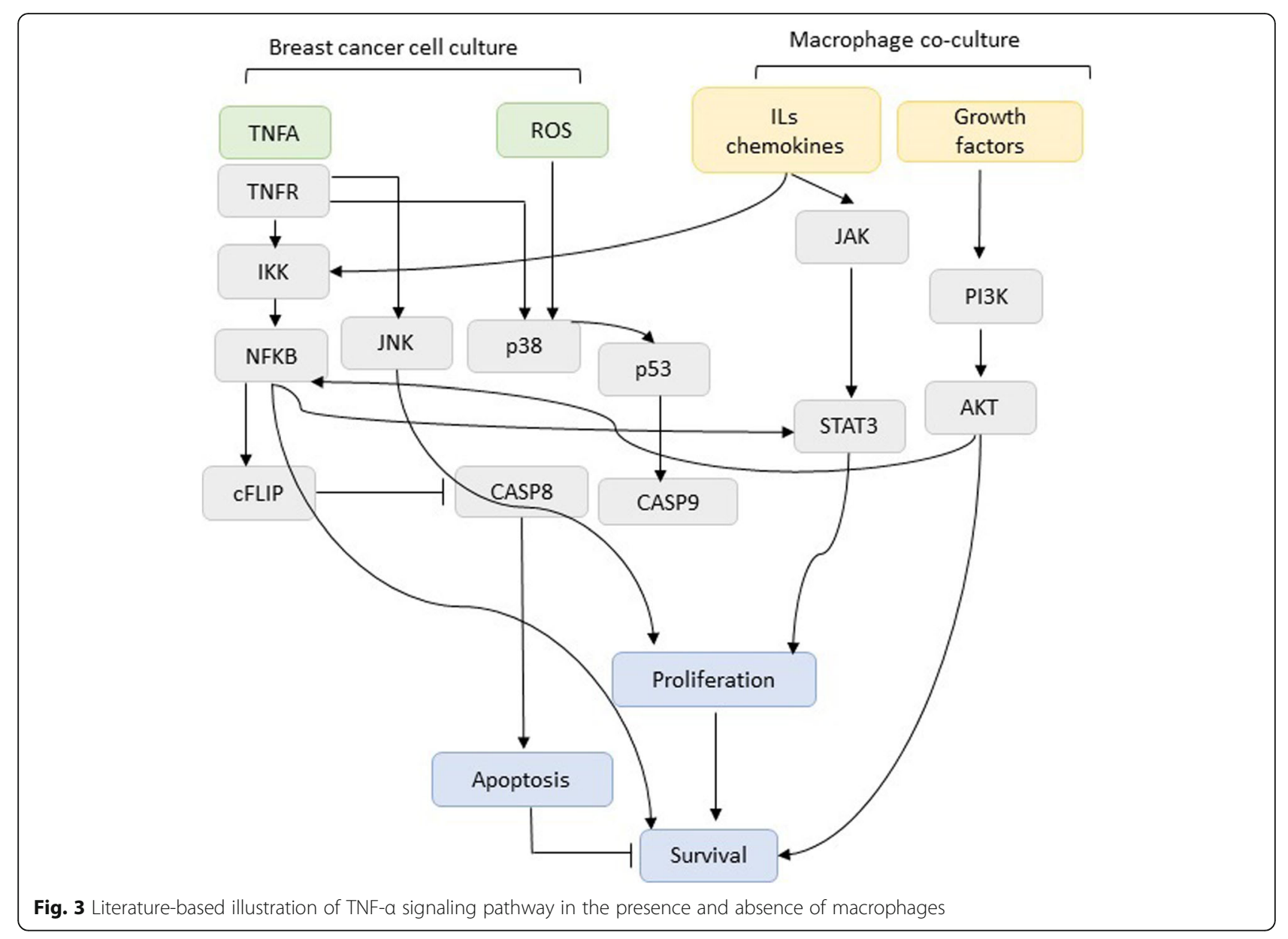




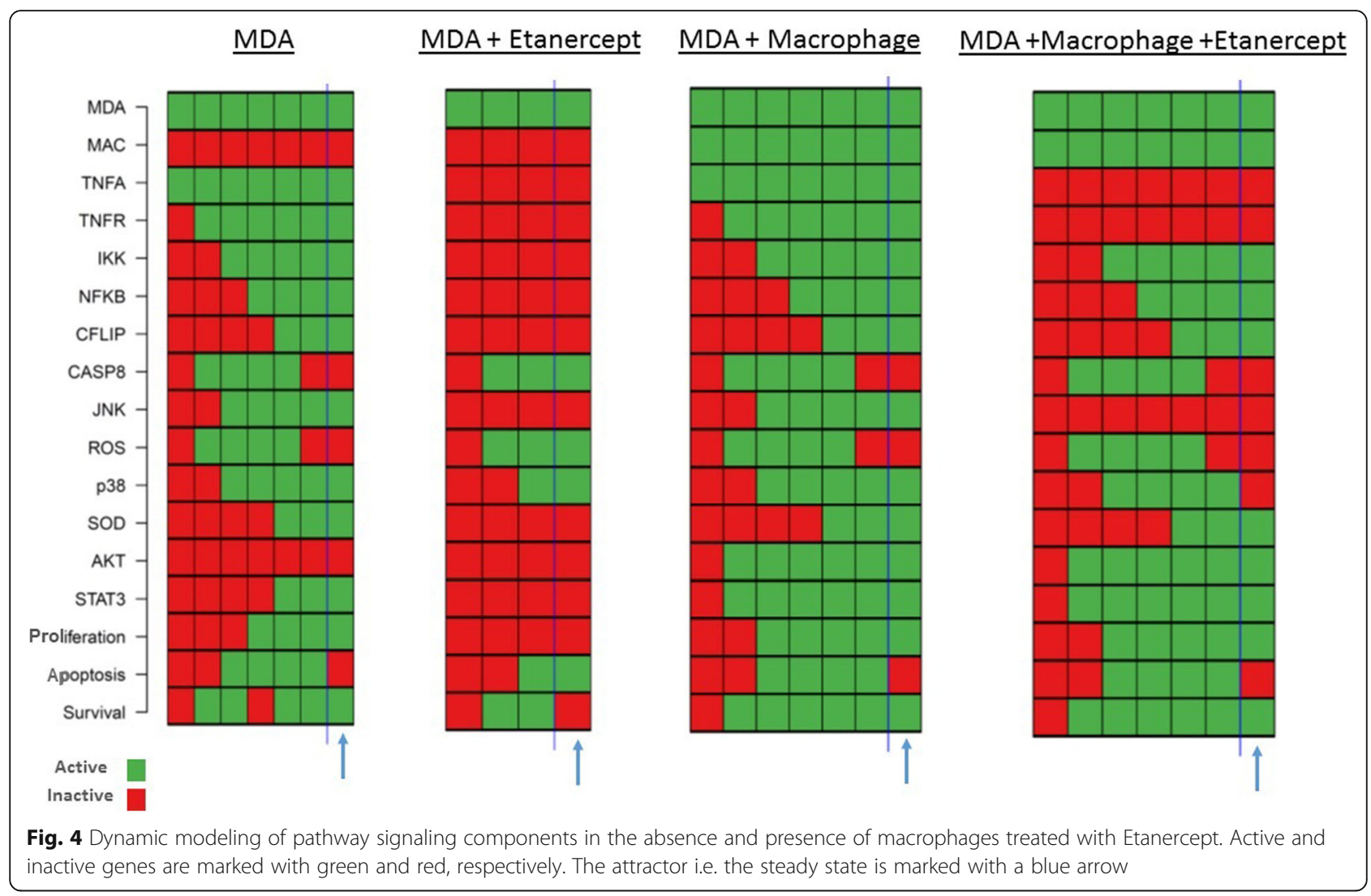

\section{Author details}

'School of Pharmacy, International Campus, Tehran University of Medical Sciences, Tehran, Iran. ${ }^{2}$ Biopharmaceutical Research Center, AryoGen

Pharmed Inc., Alborz University of Medical Sciences, Karaj, Iran. ${ }^{3}$ Physiology and Pharmacology Department, Pasteur Institute of Iran, P.O. Box: 13164,

Tehran, Iran

\section{Published online: 20 November 2020}

\section{Reference}

1. Shirmohammadi E, Ebrahimi SS, Farshchi A, et al. The efficacy of etanercept as anti-breast cancer treatment is attenuated by residing macrophages. BMC Cancer. 2020;20:836 https://doi.org/10.1186/s12885-020-07228-y. 